\title{
ЕФЕКТИВНІСТЬ ВИРОЩУВАННЯ ТЕЛЯТ 3 ВИКОРИСТАННЯМ НОВОГО ЗАМІННИКА ЦІЛЬНОГО МОЛОКА
}

Радчиков Василь Федорович

доктор сільськогосподарських наук, професор РУП «Науково-практичний центр НАН Білорусі з тваринництва» ORCID: 0000-0003-4090-6635 E-mail: arud22222@gmail.com

Цай Віктор Петрович кандидат сільськогосподарських наук, доцент РУП «Науково-практичний центр НАН Білорусі з тваринництва» ORCID: 0000-0002-1603-557X E-mail: arud22222@gmail.com

\section{Бесараб Геннадій Васильович} науковий співробітник РУП «Науково-практичний центр НАН Білорусі з тваринництва» ORCID: 0000-0001-8154-4808 E-mail: arud22222@gmail.com

Вечорка Вікторія Вікторівна доктор сільськогосподарських наук, профресор Сумський національний аграрний університет, м. Суми, Україна ORCID: 0000-0003-4956-2074

E-mail: viktoriia.vechorka@snau.edu.ua

Дослідження з вивчення ефективності вирощування телят у віці 10-65 днів з використанням замінника цільного молока проведені на двох групах телят середньої живої маси 44,3-45,6 ке. Відмінності у годівлі полягали у тому, що телятам контрольної групи випоювали молоко цільне, а дослідної - замінник цільного молока. Дослідженнями встановлено, що в 1 ке замінника цільного молока містилося обмінної енергії 16,6 МДж, сирого протеїну - 200 г, сирого жиру - 160 г, сирої клітковини - 15 г. В раціонах містилося 2,52 і 2,49 корм. од., де на 1 ке сухої речовини припадало 1,54-1,72 корм. од., на 1 кормову одиницю - 119,4-116,7 г перетравного протеїну. За кількістю сирого протеїну між групами суттєвих відмінностей не спостерігалося. Даний показник знаходився у межах 345,6-353,5 г. На підставі аналізу встановлено, що у крові дослідних тварин спостерігався підвищений вміст лейкоцитів на 7,7\%, гемоглобіну - на 2,9\%, загального білка - на 2,8\%. Водночас концентрація сечовини та еритроцитів знизилась на 4,3 і 1,6\% відносно контрольних значень. Результати досліджень показали, що найвищу енергію росту мали телята, які споживали раціон з цільним молоком, у зв'язку з чим валовий приріст молодняку I групи за дослід виявився вищим на 2,5\% по відношенню до тварин II групи. Згодовування замінника цільного молока телятам у віці 10-65 днів забезпечило зниження вартості добового раціону, що відповідно сприяло зниженню собівартості приросту живої маси телят на 16,3\%. Таким чином, випоювання замінника цільного молока телятам у віці 10-65 днів, з тривалістю молочного періоду 65 днів, позитивно вплинуло на поїдання кормів, фізіологічний стан та склад крові дослідних тварин, усі досліджувані показники знаходилися в межах фрізіологічних норм, 8 результаті за період досліду у тварин контрольної групи середньодобовий приріст виявився вищим на 2,9\%. Випоювання телятам ЗЦМ дає змогу знизити вартість раціону на 18,8\% та собівартість приросту - на 16,3\%.

Ключові слова: молодняк великої рогатої худоби, цільне молоко, замінник цільного молока, раціони, кров, продуктивність, економічна ефрективність.

DOI: https://doi.org/10.32845/bsnau.Ivst.2021.2.20

Технологія вирощування молодняку великої рогатої худоби складається 3 трьох технологічних циклів: вирощування, дорощування та відгодівля, які включають в себе молочний та післямолочний періоди, період інтенсивного росту, заключна відгодівля [1-3].

Правильне вирощування телят має вирішальне значення для успішного молочного та м'ясного скотарства. Лише здорові тварини здатні повністю використовувати генетичний потенціал для отримання максимальної продуктивності.

у новонароджених телят травна система відрізняється незавершеністю розвитку: у них слабо розви-

нені передшлунки - у перші три тижні життя теляти співвідношення об'ємів рубця та сичуга становить 1:2; у 6тижневого - 2:3; у 8-тижневого - 3:2; у 10-тижневого - 2:1. У дорослої тварини на сичуг припадає лише $8 \%$ загальної ємності шлунку, у той час як на рубець - $80 \%[4,5]$.

Наявність в раціоні телят рідкого корму у великих кількостях, а цей вид корму для телят молодшого віку є найбільш привабливим за смаком, призводить до того, що тварини поїдають відносно менше сухих кормів. Починаючи з другого місяця телят поступово привчають до рослинних кормів [6-10].

Молодняк великої рогатої худоби з моменту народ- 
ження до 6-місячного віку енергійно росте, у нього формуються кістяк, м'язова система, внутрішні органи, що потребує певну кількість енергії, поживних та біологічно-активних речовин.

Використання у годівлі телят значної кількості молока поряд з подорожчанням вирощування тварин призводить до різкого зниження товарності молока та виключає його зі сфери безпосереднього використання людиною. У зв'язку з цим при вирощуванні телят використовуються замінники цільного молока. Проте для успішного їх застосування необхідно дотримуватися певних вимог. За поживною цінністю ЗЦМ повинні бути еквівалентними цільному молоку, а за окремими показниками перевершувати його. Неможна повністю замінювати усі компоненти молока рослинними [1115].
Мета досліджень - розробити замінник цільного молока та вивчити ефективність його використання у годівлі телят у віці 10-65 днів.

Матеріал та методи досліджень. Для проведення досліджень відібрані зразки кормів, які використовувалися у годівлі телят (молочні корми, комбікорм КР-1, зерносуміш, сіно злаково-бобове, соєва макуха). Аналіз хімічного складу кормів проводили у лабораторії біохімічних аналізів РУП «Науково-практичний центр Національної академії наук Білорусі з тваринництва» за загальноприйнятими методиками зоотехнічного аналізу.

Для науково-господарського досліду були відібрані дві групи телят середньою живою масою 44,3-45,6 кг. Тварини перебували в індивідуальних будиночках. Тривалість облікового періоду становила 55 днів (табл. 1).

Таблиця 1

\section{Схема досліду}

\begin{tabular}{|l|c|c|l|}
\hline \multicolumn{1}{|c|}{ Група } & $\begin{array}{c}\text { Кількість тварин, } \\
\text { гол. }\end{array}$ & $\begin{array}{c}\text { Тривалість досліду, } \\
\text { днів }\end{array}$ & \multicolumn{1}{c|}{ Характеристика годівлі } \\
\hline I контрольна & 10 & 55 & Основний раціон (ОР) - цільне молоко, мюслі, сіно, сінаж, комбікорм КР-1 \\
\hline ІІ дослідна & 10 & 55 & ОР + 3ЦМ \\
\hline
\end{tabular}

Усе піддослідне поголів'я знаходилося в однакових умовах: годівля телят протягом досліду здійснювалася двічі на добу, напування - з відер. ЗЦМ готували перед кожним випоюванням у співвідношенні 1:9. Привчання до споживання здійснювали поступово, протягом 5 днів.

Відмінності у годівлі полягали у тому, що телятам контрольної групи випоювали молоко цільне, а молодняку дослідної групи - замінник цільного молока.

У ході досліджень використані зоотехнічні, біохімічні та математичні методи.

Отриманий цисровий матеріал опрацьовували методом варіаційної статистики з урахуванням критерію достовірності Стьюдента з використанням програмного пакету MickosoftExcel.

Результати досліджень. Для проведення експериментів розроблений дослідний замінник цільного молока (табл. 2).

Таблиця 2

Склад та поживність дослідного ЗЦМ

\begin{tabular}{|l|c|}
\hline \multicolumn{1}{|c|}{ Інгредієнт, \% } & ЗЦМ \\
\hline Молочні білки & 36,99 \\
\hline Сироватково-жировий концентрат & 32,0 \\
\hline Рослинні білки & 30,0 \\
\hline Вітамінно-мінеральний комплекс & 1,0 \\
\hline Ароматична добавка & 0,01 \\
\hline \multicolumn{2}{|c|}{ В 1 кг міститься: } \\
\hline Обмінної енергї̈, МДж & 16,6 \\
\hline Сирого протеїну, г & 200 \\
\hline Сирого жиру, г & 160 \\
\hline Сирої клітковини, г & 15 \\
\hline
\end{tabular}

В 1 кг молочного продукту містилося обмінної енергії 16,6 МДж, сирого протеїну - 200 г, сирого жиру - 160 г, сирої клітковини - 15 г.

До висококрохмалистих концентратів (мюслі, комбікорм КР-1) телят починали привчати з 14-денного віку. Саме ці тверді корми на даний період онтогенезу найкращим чином стимулюють розвиток ворсинок та абсорбуючу здатність рубця, прискорюючи розвиток передшлункового травлення (на відміну від молока і його замінників у рідкому вигляді, минаючи рубець), і як наслідок, його целюлозолітичну активність.

Використання у годівлі телят цільного молока та його замінника позитивно вплинуло на споживання корму (табл. $3)$.

Таблиця 3

\section{Раціони піддослідних тварин (за фрактично спожитими кормами)}

\begin{tabular}{|c|c|c|c|c|}
\hline \multirow{3}{*}{ Корми та поживні речовини } & \multicolumn{4}{|c|}{ Група } \\
\hline & \multicolumn{2}{|c|}{$\mathrm{I}$} & \multicolumn{2}{|c|}{$\|$} \\
\hline & Кг & $\%$ & Кг & $\%$ \\
\hline Молоко цільне & 6,00 & 64,3 & - & - \\
\hline Замінник цільного молока & - & & 0,75 & 66,3 \\
\hline Комбікорм КР-1 & 0,46 & 21,6 & 0,45 & 21,3 \\
\hline Мюслі & 0,20 & 9,0 & 0,17 & 7,6 \\
\hline Сіно злакове & 0,20 & 4,0 & 0,18 & 3,3 \\
\hline Сінаж різнотравний & 0,15 & 1,1 & 0,13 & 1,5 \\
\hline \multicolumn{5}{|c|}{ В раціоні міститься } \\
\hline Кормових одиниць & \multicolumn{2}{|c|}{2,52} & \multicolumn{2}{|c|}{2,49} \\
\hline Обмінної енергії, МДж & \multicolumn{2}{|c|}{22,90} & \multicolumn{2}{|c|}{20,61} \\
\hline Сухої речовини, кг & \multicolumn{2}{|c|}{1640,0} & \multicolumn{2}{|c|}{1448,8} \\
\hline Сирого протеїну, г & \multicolumn{2}{|c|}{353,5} & \multicolumn{2}{|c|}{345,6} \\
\hline Перетравного протеїну, г & \multicolumn{2}{|c|}{301,0} & \multicolumn{2}{|c|}{291,0} \\
\hline Сирого жиру, г & \multicolumn{2}{|c|}{236,0} & \multicolumn{2}{|c|}{149,0} \\
\hline Сирої клітковини, г & \multicolumn{2}{|c|}{95,9} & \multicolumn{2}{|c|}{93,7} \\
\hline Крохмалю, г & \multicolumn{2}{|c|}{64,1} & \multicolumn{2}{|c|}{54,7} \\
\hline Цукру, г & \multicolumn{2}{|c|}{270,1} & \multicolumn{2}{|c|}{240,5} \\
\hline Кальцію, г & \multicolumn{2}{|c|}{16,6} & \multicolumn{2}{|c|}{16,3} \\
\hline Фосфору, г & \multicolumn{2}{|c|}{10,6} & \multicolumn{2}{|c|}{9,5} \\
\hline Магнію, г & \multicolumn{2}{|c|}{1,6} & \multicolumn{2}{|c|}{1,3} \\
\hline Калію, г & \multicolumn{2}{|c|}{14,0} & & \\
\hline Сірки, г & & & & \\
\hline Заліза, мг & & & & \\
\hline Міді, мг & & & & \\
\hline Цинку, мг & & & & \\
\hline Марганцю, мг & & & & \\
\hline Кобальту, мг & & & & \\
\hline Йоду, мг & & & & \\
\hline Каротину, мг & & & & \\
\hline Вітаміну Д, тис. МО & & & & \\
\hline Вітаміну E, мг & & & & \\
\hline
\end{tabular}


Дослідженнями встановлено, що у раціонах містилося 2,52 і 2,49 корм. од., де на 1 кг сухої речовини припадало 1,54-1,72 корм. од., на 1 кормову одиницю - 119,4-116,7 г перетравного протеїну.

За кількістю сирого протеїну між групами значних відмінностей не встановлено. Даний показник знаходився в межах 345,6-353,5 г.

За вмістом обмінної енергії раціонів не виявлено суттєвих відмінностей між досліджуваними групами. У 1 кг сухо ̈ речовини містилося 20,90 та 20,61 МДж ОЕ. На 1 МДж ОЕ припадало 13,1 та 14,1 г перетравного протеїну.

Включення до раціону ЗЦМ не мало негативного впливу на склад крові тварин, усі досліджувані показники знаходилися в межах фізіологічних норм (табл. 4).

\section{Морфо-біохімічний склад крові телят}

\begin{tabular}{|l|c|c|}
\hline \multirow{2}{*}{\multicolumn{1}{|c|}{ Показник }} & \multicolumn{2}{|c|}{ Група } \\
\cline { 2 - 3 } & $\mathrm{I}$ & $\mathrm{I}$ \\
\hline Еритроцити, 1012/л & $7,66 \pm 0,1$ & $7,54 \pm 0,15$ \\
\hline Лейкоцити, 109/л & $5,73 \pm 0,13$ & $6,17 \pm 1,22$ \\
\hline Гемоглобін, г/л & $103 \pm 0,88$ & $106 \pm 1,2$ \\
\hline Загальний білок, г/л & $58,67 \pm 1,36$ & $60,33 \pm 1,24$ \\
\hline Глюкоза, ммоль/л & $5,83 \pm 0,29$ & $5,33 \pm 0,54$ \\
\hline Сечовина, ммоль/л & $4,87 \pm 0,53$ & $4,66 \pm 0,29$ \\
\hline Тромбоцити, 109/л & $397,81 \pm 1,58$ & $386,14 \pm 1,81$ \\
\hline Гематокрит, \% & $17,83 \pm 0,31$ & $16,8 \pm 1,08$ \\
\hline
\end{tabular}

У крові дослідних тварин спостерігалося збільшення вмісту лейкоцитів на 7,7\%, гемоглобіну - на 2,9\%, загального білку - на 2,8\%. Водночас концентрація сечовини, еритроцитів знизилася на 4,3 та 1,6\% по відношенню до контрольних значень.

Результати досліджень мінливості живої маси показали, що найвищу енергію росту мали телята, які споживали раціон з цільним молоком, у зв'язку з чим їхній валовий приріст виявився на 2,5\% вищим.

Середньодобовий приріст живої маси телят у контрольній групі склав 683,6 г, у дослідній - 663 г, що на 2,9\% нижче у порівнянні з аналогами. Витрати кормів на отримання приростів у тварин контрольної групи незначною мірою знизилися - на 1,6\% у порівнянні 3 дослідним молодняком (табл. 5).

Таблиця 5

Мінливість живої маси та середньодобові прирости

\begin{tabular}{||l|c|c|}
\hline \multicolumn{1}{|c|}{ Показник } & \multicolumn{2}{c|}{ Група } \\
\cline { 2 - 3 } & I & II \\
\hline Жива маса, кг: на початку досліду & $44,38 \pm 1,08$ & $45,64 \pm 1,19$ \\
\hline в кінці досліду & $81,88 \pm 1,97$ & $82,15 \pm 2,16$ \\
\hline Валовий приріст, кг & $37,60 \pm 1,69$ & $36,51 \pm 2,5$ \\
\hline Середньодобовий приріст, г & $683 \pm 25,1$ & $663 \pm 45,75$ \\
\hline \% до контролю & 100,0 & 97,1 \\
\hline Витрати кормів на 1 кг приросту, корм. од. & 3,69 & 3,75 \\
\hline
\end{tabular}

Згодовування замінника цільного молока телятам у віці 10-65 днів дослідної групи забезпечило зменшення вартості добового раціону на 18,8\%, що сприяло зниженню собівартості приросту живої маси телят на 16,3\%.

Висновки. Використання цільного молока у годівлі телят у віці 10-65 днів, з тривалістю молочного періоду 65 днів, мало позитивний вплив на поїдання кормів, фізіологічний стан та склад крові дослідних тварин, усі досліджувані показники знаходилися в межах фізіологічних норм. У крові тварин збільшився вміст лейкоцитів на 7,7\%, гемоглобіну - на 2,9\%, загального білку - на 2,8\%, у той час як концентрація сечовини та еритроцитів знизилася на 4,3 і 1,6\%. В результаті за період досліду у тварин дослідної групи отримано 663 г середньодобового приросту, що на $2,9 \%$ нижче контрольного показника. Випоювання телятам ЗЦМ дозволяє знизити вартість раціону на $18,8 \%$ та собівартість приросту - на 16,3\%.

\section{Список використаної літератури:}

1. Ганущенко, О.Ф. Эффрективность новых заменителей цельного молока при выращивании телят / О.Ф. Ганущенко // Зоотехническая наука Беларуси. 2010. Т. 45. № 2. С. 35-43.

2. Продуктивность пайзы и использование ее для заготовки силоса / Истранин Ю.В., Зиновенко А.Л. / Ученые записки учреждения образования Витебская ордена Знак почета государственная академия ветеринарной медицины. 2009. Т. 45. № 1-2. C. 34-37.

3. Рациональное использование кормовых ресурсов и профилактика нарушений обмена веществ у животных в стойловый период / В.Б. Славецкий [и др.] // рекомендации / Учреждение образования "Витебская ордена "Знак Почета" государственная академия ветеринарной медицины". Витебск, 2002.

4. Мясная продуктивность и качество говядины при скармливании кормовой добавки гумат натрия/ Г.Н.Радчикова, Л.А.Возмитель, И.В.Сучкова, В.Г.Стояновский, М.М.Брошков, С.Г.Зиновьев//Вісник Сумьского національного аграрного університету. Серія «Тваринництво», вип. 5/2 (32), 2017. -С. 137-142.

5. Скармливание дефеката кормового в комбикормах крупного рогатого скота/А.М. Глинкова, Г.Н. Радчикова, В.П. Цай, Т.Л. Сапсалёва// Матеріали Міжнародної науково-практичної конфреренції «Стратеічі напрями розвитку тваринництва в Україі у контексті наіональної продовольчої безпеки», присвяченої заснування кафедри технології виробництва молока та м'яса і 90-річчю від дня народження видатного вченого-технолога, доктора с.-г. наук, професора Адміна, 30-31 жовтня 2014 року, Біла Церква, 2014. - С. 27-28

6. Переваримость, использование питательных веществ и продуктивность молодняка крупного рогатого скота при скармливании биологически активной добавки / Богданович Д.М., Разумовский Н.П. В сборнике: Селекционно-генетические и технологические аспекты производства продуктов животноводства, актуальные вопросы безопасности жизнедеятельности и медицины. Материалы международной научно-практической конфреренции посвященной 90-летнему юбилею биотехнологического факультета. 2019. С. 13-23.

7. Эфффективность включения в рацион бычков новой кормовой добавки / Богданович Д.М., Разумовский Н.П. / В сборнике: Селекционно-генетические и технологические аспекты производства продуктов животноводства, актуальные вопросы безопасности жизнедеятельности и медицины. Материалы международной научно-практической конференции посвященной 90-летнему юбилею биотехнологического факультета. 2019. С. 75-80. 
8. Микробиологические показатели и количество соматических клеток при хранении молока коз-продуцентов RHLF второго и третьего года лактации / Богданович Д.М., Будевич А.И., Петрушко Е.В. В сборнике: Новые подходы к разработке технологий производства и переработки сельскохозяйственной продукции. Материалы Международной научнопрактической конференции. Под общ. ред. И.Ф. Горлова . 2018. С. 135-140.

9. Яковчик, С.Г. Новый концентрат в составе заменителей цельного молока при выращивании телят / С.Г. Яковчик, О.Ф. Ганущенко // Весці Нацыянальнай акадэміі навук Беларусі. Серыя аграрных навук. 2011. № 4. С. 89-94.

10. Эффрективность скармливания телятам кормовой добавки "ПМК" Богданович Д.М., Разумовский Н.П. В сборнике: Научные основы производства и обеспечения качества биологических препаратов для АПК. Материалы Международной научно-практической конференции, посвященной 50-летию института. Под редакцией А.Я. Самуйленко. 2019. С. 401-405.

11. Ганущенко О.Ф. Современные подходы к оценке качества кормов / О.Ф. Ганущенко, Н.П. Разумовский // Наше сельское хозяйство. 2015. № 22. С. 46.

12. Какой заменитель молока нужен телёнку / Радчикова Г.Н., Трокоз В.А., Карповский В.И., Брошков М.М., Стояновский В.Г., Кот А.Н., Цай В.П., Бесараб Г.В. В сборнике: Инновационные технологии в сельском хозяйстве, ветеринарии и пищевой промышленности. Материалы 83-й международной научно-практической конфееренции. 2018. С. 130-136.

13. Влияние количества протеина в составе заменителей цельного молока на продуктивность телят в возрасте 10-30 дней/ Г.Н. Радчикова, А.Н. Кот, Н.А. Яцко, Н.А. Шарейко, Л.А. Возмитель, В.В. Букас, И.В. Сучкова// Вісник Сумьского національного аграрного університету. Серія «Тваринництво», вип. 2 (34), 2018.-С. 209-213

14. Эфффективность использования кормов с углеводной основой при выращивании ремонтантного молодняка крупного рогатого скота / Приловская Е.И., Кот А.Н., Радчикова Г.Н., Сапсалёва Т.Л., Богданович Д.М.І В сборнике: От инерции к развитию: научно-инновационное обеспечение развития животноводства и биотехнологий. Сборник материалов международной научно-практической конференции "От инерции к развитию: научно-инновационное обеспечение АПК". 2020. С. 164167.

15. Природный микробный комплекс в кормлении молодняка крупного рогатого скота / Богданович Д.М., Разумовский Н.П. В сборнике: Инновационное развитие аграрно-пищевых технологий. Материалы Международной научно-практической конференции. Под общей редакцией И.Ф. Горлова. 2020. С. 22-26

16. Формируем из телки корову с «большой карьерой» / Лапотко А.М., Зиновенко А.Л., Песоцкий Н.И. Наше сельское хозяйство. 2009. № 8. С. 23.

17. Микроэлементы в органической форме в кормлении молодняка крупного рогатого скота / В.Ф. Радчиков [и др.] // В сборнике: Инновационные технологии в сельском хозяйстве, ветеринарии и пищевой промышленности. Сборник научных статей по материалам 82-й Международной научно-практической конференции. 2017. С. 197-202.

18. Ганущенко, О.Ф. Эффективность использования новых вариабельно-возрастных видов заменителей цельного молока при выращивании телят / О.Ф. Ганущенко, Л.С. Боброва, В.В. Славецкий // Зоотехническая наука Беларуси. 2012. Т. 47. № 2. C. 31-40.

19. Разные нормы лактозы в кормлении телят /Т.Л. Сапсалёва, Г.Н. Радчикова,С.А. Ярошевич, Е.П. Симоненко, В.А. Медведский, В.Г. Стояновский, Л.М. Дармограй, С.Г. Зиновьев// Проблеми виробництва і переробки продовольчої сировини та якость і безпечність харчових продукктів. Збірнік наукових праць II міжнародної науково-практичної конференції. - Житомир, 2020. - С. 240-244.

20. Эфффективность использования 3ОМ с различным включением молочного сахара в комбикорме КР-2 для молодняка крупного рогатого скота/ Г.Н. Радчикова, С.Н. Пилюк, С.В. Сергучев, А.Н. Кот, Л.А.Возмитель, М.М.Брошков, А.В.Данчук, С.Г.Стояновский, Л.М.Дармаграй// Актуальні проблеми підвищення якості та безпека виробництва й переробки продукціі тварнництва. Матеріали міжнародноі науково-практичноі конференціі (14 лютого 2020 року), Дніпро, 2020. - С. 62-65.

\section{References:}

1. Ganushchenko O. F. 2010. Jeffektivnost' novyh zamenitelej cel'nogo moloka pri vyrashhivanii teljat [The effectiveness of new substitutes for whole milk in the rearing of calves]. Zootehnicheskaja nauka Belarusi. Zhodino, T. 45, part 2, pp. 35-43.

2. Istranin Yu. V., Zinovenko A. L. 2009. Produktivnost' pajzy i ispol'zovanie ee dlja zagotovki silosa [Productivity of paise and its use for silage procurement]. Uchenye zapiski uchrezhdenija obrazovanija Vitebskaja ordena Znak pocheta gosudarstvennaja akademija veterinarnoj mediciny, issue 45, no 1(2), pp. 34-37.

3. Slavecky V. B., Ganushchenko O. F., Pakhomov I. Ya., Razumovsky N. P., Belko A. A., Makarevich G. F., Demyanovich E. P., Khitrinov G. M. 2002. Racional'noe ispol'zovanie kormovyh resursov i profilaktika narushenij obmena veshhestv u zhivotnyh v stojlovyj period : rekomendacii [Rational use of forage resources and prevention of metabolic disorders in animals during the stall period : recommendations]. Vitebsk, $54 \mathrm{p}$.

4. Radchikova G. N., Vozmitel' L. A., Suchkova I. V., Stojanovskij V. G., Broshkov M. M., Zinov'ev S. G. 2017. Mjasnaja produktivnost' i kachestvo govjadiny pri skarmlivanii kormovoj dobavki gumat natrija [Meat productivity and quality of beef when feeding the feed additive sodium humate]. Visnyk Sumskoho NAU. Seriia «Tvarynnytstvo», issue 5/2(32), pp. 137-142.

5. Glinkova A. M., Radchikova G. N., Caj V. P., Sapsaljova T. L. 2014. Skarmlivanie defekata kormovogo v kombikormah krupnogo rogatogo skota [Feeding the feed defecate in the compound feeds of cattle]. In: Strategic directions of animal husbandry development in Ukraine in the context of national food security: materials of the International scientific-practical conference, dedicated to the establishment of the department of milk and meat production technology and the 90th anniversary of the outstanding scientist-technologist, doctor of agricultural sciences. Sciences, Professor Admin, October 30-31, 2014. Bila Tserkva, pp. 27-28.

6. Bogdanovich D. M., Razumovskij N. P. 2019. Perevarimost', ispol'zovanie pitatel'nyh veshhestv i produktivnost' molod- 
njaka krupnogo rogatogo skota pri skarmlivanii biologicheski aktivnoj dobavki [Digestibility, nutrient utilization and productivity of young cattle when feeding a dietary supplement]. In: Selection-genetic and technological aspects of the production of livestock products, topical issues of life safety and medicine : materials of the international scientific-practical conference dedicated to the 90 -year anniversary of the Faculty of Biotechnology. Vitebsk, pp. 13-23.

7. Bogdanovich D. M., Razumovskij N. P. 2019. Jeffektivnost' vkljuchenija v racion bychkov novoj kormovoj dobavki [Efficiency of inclusion of a new feed additive in the diet of bull calves]. In: Selection-genetic and technological aspects of the production of livestock products, topical issues of life safety and medicine : materials of the international scientific-practical conference dedicated to the 90-year anniversary of the Faculty of Biotechnology. Vitebsk, pp. 75-80.

8. Bogdanovich D. M., Budevich A. I., Petrushko E. V. 2018. Mikrobiologicheskie pokazateli i kolichestvo somaticheskih kletok pri hranenii moloka koz-producentov RHLF vtorogo i tret'ego goda laktacii [Microbiological parameters and number of somatic cells during storage of milk of goat producers RHLF of the second and third year of lactation]. In: New approaches to the development of technologies for production and processing of agricultural products : materials of the International scientific-practical conference. Volgograd, pp. 135-140.

9. Yakovchik S. G., Ganushchenko O. F. 2011. Novyj koncentrat v sostave zamenitelej cel'nogo moloka pri vyrashhivanii teljat [A new concentrate in the composition of whole milk substitutes in the rearing of calves]. Vesci Nacyjanal'naj akadjemii navuk Belarusi. Seryja agrarnyh navuk, no 4, pp. 89-94.

10. Bogdanovich D. M., Razumovsky N. P. 2019. Jeffektivnost' skarmlivanija teljatam kormovoj dobavki "PMK" [The effectiveness of feeding calves feed additive "PMK"]. In: Scientific bases of production and quality assurance of biological products for agriculture : materials of the International scientific-practical conference dedicated to the 50th anniversary of the institute, September 25-27, 2019, Shchelkovo, pp. 401-405.

11. Ganushchenko O. F., Razumovsky N. P. 2015. Sovremennye podhody k ocenke kachestva kormov [Modern approaches to assessing the quality of feed]. Nashe sel'skoe hozjajstvo, no 22, p. 46.

12. Radchikova G. N., Trokoz V. A., Karpovsky V. I., Broshkov M. M., Stojanovsky V. G., Kot A. N., Caj V. P., Besarab G. V. 2018. Kakoj zamenitel' moloka nuzhen teljonku [What milk replacer does a calf need?]. In: Innovative technologies in agriculture, veterinary medicine and food industry : materials of the 83rd international scientific-practical conference. Stavropol, pp. 130-136.

13. Radchikova G. N., Kot A. N., Yatsko N. A., Sharejko N. A., Vozmitel' L. A., Bukas V. V., Suchkova I. V. 2018. Vlijanie kolichestva proteina $v$ sostave zamenitelej cel'nogo moloka na produktivnost' teljat v vozraste 10-30 dnej [Influence of the amount of protein in the composition of whole substitutes milk on the productivity of calves aged 10-30 days]. Visnyk Sumskoho NAU. Seriia «Tvarynnytstvo», issue 2(34), pp. 209-213.

14. Prilovskaya E. I., Kot A. N., Radchikova G. N., Sapsalyova T. L., Bogdanovich D. M. 2020. Jeffektivnost' ispol'zovanija kormov s uglevodnoj osnovoj pri vyrashhivanii remontantnogo molodnjaka krupnogo rogatogo skota [The efficiency of the use of feed with a carbohydrate basis in the cultivation of remontant young cattle]. In: From inertia to development: scientific and innovative support for the development of animal husbandry and biotechnology: Proceedings of the International Scientific and Practical Conference "From Inertia to Development: Scientific and Innovative Support of AIC", Yekaterinburg, February 18-19 2020, pp. 164-167.

15. Bogdanovich D. M., Razumovskij N. P. 2020. Prirodnyj mikrobnyj kompleks v kormlenii molodnjaka krupnogo rogatogo skota [Natural microbial complex in the feeding of young cattle]. In: Innovative development of agricultural and food technologies: materials of the International scientific-practical conference, Volgograd, pp. 22-26.

16. Lapotko A. M., Zinovenko A. L., Pesotsky N. I. 2009. Formiruem iz telki korovu s «bol'shoj kar'eroj» [We form from a heifer a cow with "big career"]. Nashe sel'skoe hozjajstvo, no 8, pp. 23.

17. Radchikov V. F., Tsay V. P., Kot A. N., Gorlov I. F., Lyundyshev V. A., Sharejko N. A., Kurtina V. N., Ganushchenko O. F. 2017. Mikrojelementy v organicheskoj forme $v$ kormlenii molodnjaka krupnogo rogatogo skota [Microelements in organic form in the feeding of young cattle]. In: Innovative technologies in agriculture, veterinary medicine and food industry: materials of the 82nd International scientific-practical conference. Stavropol, pp. 197-202.

18. Ganushchenko O. F., Bobrova L. S., Slavetsky V. V. 2012. Jeffektivnost' ispol'zovanija novyh variabel'no-vozrastnyh vidov zamenitelej cel'nogo moloka pri vyrashhivanii teljat [The effectiveness of the use of new variable-age species of whole milk substitutes in calf rearing]. Zootehnicheskaja nauka Belarusi. Zhodino, T. 47, part 2, pp. 31-40.

19. Sapsalyova T. L., Radchikova G. N., Yaroshevich S. A., Simonenko E. P., Medvedsky V. A., Stoyanovsky V. G., Darmogray L. M., Zinov'ev S. G. 2020. Raznye normy laktozy v kormlenii teljat [Various norms of lactose in the feeding of calves]. In: Problems of production and processing of food raw materials and quality and safety of food products: collection of scientific works of the II international scientific-practical conference. Zhytomyr, pp. 240-244.

20. Radchikova G. N., Pilyuk S. N., Serguchev S. V., Kot A. N., Vozmitel' L. A., Broshkov M. M., Danchuk A. V., Stoyanovsky S. G., Darmagray L. M. 2020. Jeffektivnost' ispol'zovanija ZOM s razlichnym vkljucheniem molochnogo sahara v kombikorme KR-2 dlja molodnjaka krupnogo rogatogo skota [Efficiency of using ZOM with different inclusions of milk sugar in the KR-2 compound feed for young cattle]. In: Actual problems of quality improvement and safety of production and processing of livestock products : materials of the international scientific-practical conference, February 14, 2020 Dnipro, pp. 62-65. 
Radchykov Vasyl Fedorovych, Doctor Agricultural Sceiences, Professor,

Tsai Viktor Petrovych, CSc.(Agriculture), assistant professor,

Besarab Hennadii Vasylovych, Researcher

Republican Unitary Enterprise «Scientific Practical Centre of Belarus National Academy of Sciences on Animal Breeding»

(Zhodino, Belarus)

Vechorka Viktoriia Viktorivna, Doctor of Agricultural Sciences, Professor, Sumy National Agrarian University (Sumy, Ukraine)

Efficiency of raising calves using new whole milk replacer

Studies of efficiency of calves rearing at the age of 10-65 days using whole milk replacer have been carried out with two groups of calves with an average body weight of 44.3-45.6 kg. Differences in feeding consisted in the fact that the calves of the control group were fed with whole milk, and the experimental one - with whole milk replacer. Studies have shown that $1 \mathrm{~kg}$ of whole milk replacer contained $16.6 \mathrm{MJ}$ of metabolizable energy, crude protein $-200 \mathrm{~g}$, crude fat $-160 \mathrm{~g}$, crude fiber $-15 \mathrm{~g}$. The diets contained 2.52 and 2.49 feed units, where $1 \mathrm{~kg}$ of dry matter accounted for 1.54-1.72 feed units, 1 feed unit accounted for 119.4$116.7 \mathrm{~g}$ of digestible protein. There was no significant difference in the amount of crude protein between the groups. This indicator was within the range of 345.6-353.5 grams. Based on the analysis, it has been determined that leukocytes level in the blood of experimental animals increased by $7.7 \%$, hemoglobin - by $2.9 \%$, total protein - by $2.8 \%$. At the same time, concentration of urea and erythrocytes decreased by 4.3 and $1.6 \%$ compared to the control values. The research results showed that the calves that consumed diet with whole milk had the highest growth energy, and therefore, the gross weight gain of young animals in group I during the experiment was $2.5 \%$ higher compared to animals in group II. Feeding calves with the whole milk replacer at the age of $10-65$ days reduced the cost of the daily diet, which contributed to decrease in the cost of weight gain of calves by 16.3 percent. Thus, feeding calves aged 10-65 days with the whole milk replacer, with a milk period of 65 days, had a positive effect on feed intake, physiological state and blood composition of experimental animals, all the studied parameters were within physiological standard range, as a result for the period of experiment, the average daily weight gain was $2.9 \%$ higher in animals of the control group. Feeding calves with WMR helps to reduce the cost of diet by $18.8 \%$ and the price cost of weight gain by 16.3 .

Key words: young cattle, whole milk, whole milk replacer, diets, blood, performance, economic efficiency.

Дата надходження до редакції: 13.04.2021 р. 